\title{
Biodiversity research and conservation in Cat Ba National Park with updated records from recent field surveys
}

\author{
Tổng quan tình hình nghiên cưu và bảo tồn đa dạng sinh học ở Vuờn Quốc gia \\ Cát Bà với nhũng ghi nhận cập nhật qua điều tra thực địa \\ Research article
}

Cao Thi Thanh Nga*, Nguyen Song Tung

Institute of Human Geography, Vietnam Academy of Social Science, 01 Lieu Giai, Ba Dinh, Hanoi, Vietnam

\begin{abstract}
Among the protected area system of Vietnam, Cat Ba appears as an ideal national park for biodiversity research and conservation. It covers a large area of karst landscape including islands and different ecosystems ranging from forests, wetland, mangroves, caves and others. Since the establishment of Cat Ba National Park in 1986, biodiversity research and conservation within the park have been strongly promoted and raised. The park has been well known as home to highly diverse flora and fauna with many species endemic to the archipelago and Vietnam. A series of projects and programmes have been effectively implemented for urgent and long-term conservation of threatened species. However, results from scientific research also indicated that many sites and species are still almost unstudied while several sections of the park's buffer zone are affected by human activities including unscientific development of ecotourism. We recently conduct a field survey and recorded 2 bat species and echolocation calls in their natural habitats. This paper provides an overview of achievements with recent records and recommendations for strengthening conservation of biodiversity and habitats in the park and surroundings.
\end{abstract}

Trong hệ thống khu vưc bảo vệ của Việt Nam, Cát Bà là một vuờn quốc gia có điều kiện thuận lợi đối với công tác nghiên cứu và bảo tồn đa dạng sinh học. Vuờn quốc gia này bao gồm diện tích lớn cảnh quan núi đá vôi với các đảo và hệ sinh thái đặc trung nhu rùng trên núi, đất ngập nuớc, rù̀ng ngập mặn, hang động và nhiều hệ sinh thái khác. Tù khi thành lập Vuờn Quốc gia Cát Bà năm 1986, công tác nghiên cứu và bảo tồn đa dạng sinh học được quan tâm và thực hiện ngày càng nhiều. Vuờn quốc gia cũng chứa đưng khu hệ động vật và thực vật đa dạng với nhiều loài đặc hũu cho quần đảo và Việt Nam. Nhiều dụ án và chuoong trình đã được thực hiện nhằm bảo tồn cấp bách và lâu dài nhũng loài bị đe dọa. Tuy nhiên, nhũng kết quả nghiên cứu khoa học cũng cho thấy nhiều khu vưc trong phạm vi vuò̀n quốc gia gần nhu chưa được nghiên cứu trong khi một số tiểu khu thuộc vùng đệm đang bị ảnh hưởng bởi hoạt động của con người nhu sư phát triển du lịch. Chúng tôi đã ghi nhận được 2 loài dơi cùng với tiếng kêu siêu âm trong môi truờng sống tự nhiên của chúng qua thời gian điều tra thưc địa viùa qua. Bài báo này cung cấp dẫn liệu tổng quan và cập nhật về những kết quả đã đạt được với nhũng thông tin cập nhật và đề xuất nhằm thúc đẩy công tác bảo tồn đa dạng sinh học và sinh cảnh ở vuờn quốc gia và vùng phu cận trong tuoong lai.

Keywords: biodiversity, $\mathrm{Cat} \mathrm{Ba}$, conservation, ecosystems, karst islands.

\section{Introduction}

Cat Ba National Park (CBNP) is located in the Gulf of Tonkin and covers a total area of $16,196.8$ ha comprising $5,265.7$ ha of the surrounding marine waters and 10,931.1 ha of islands [5]. The park is a "major tourist destination in northern Vietnam" [7]. The number of foreign and domestic visitors have been annually increased since 2000 and particularly since the Tan Vu-Lach Huyen bridge was built for connection between the mainland and Cat Hai island. Within 2017, a total of 2,160,000 tourists visited Cat Ba islands with an estimation of approximately 2,600,000 tourists in 2018 and continuously increased in following 
years (Hai Phong People Committee, 2018). The Cat Ba Protected Area was established in 1983 by the Ministry of Forestry and became a national park in 1986 [7]. The population of $\mathrm{Cat} \mathrm{Ba}$ island had also been rapidly increased over the past 20 years, from 10,700 people in 1999 to over 20,000 people in 2017. The local people in Cat Ba island gain major outcomes from trade, fishing farming and other activities. Of which, fishing and farming form the largest livelihoods in the islands (Furey, 2002; this study). Topograpgy of $\mathrm{Cat} \mathrm{Ba}$ island is characterised by limestone karst outcrops with the highest peak of ca. 50-331 metre above sea level interspersed with valleys. "Between the karst outcrops, the limestones are overlaid by patches of sandstone and shale as well as marine sediments (semiconsolidated to unconsolidated) laid down over the course of several fluctuations in sea level during the Quaternary and Holocene periods" [7]. Vegetation of the park is still poorly studied. Jong-Won Kim and Nguyen Nghia Thin (sensu [7]) identified the vegetation of the park as 7 main vegetation types. With the diversity of topography, geography and vegetation, Cat Ba National Park is recognised as an ideal home for biodiversity research and conservation [16]. This paper provides a precise overview of historical research and conservation of general biodiversity within the park with valuable records from recent surveys in both biodiversity and environment aspects.

\section{Materials and methods}

\subsection{Study sites}

Recent field surveys were carried out in two periods: October-November 2017 and April 2018 in 7 sites, including Cat Ba town and 6 communes (Gia Luan, Hien Hao, Phu Long, Tran Chau, Viet Hai and Xuan Dam) (table 1). These communes belong to the core and buffer zones of Cat $\mathrm{Ba}$ National Park. They contain different habitats and ecosystems ranging from plantation to primary forests.

\section{Table 1. Time and study sites}

\begin{tabular}{lll} 
No. & \multicolumn{1}{c}{ Study sites } & \multicolumn{1}{c}{ Time } \\
\hline 1 & Cat Ba town, the buffer zone and surroundings of Cat Ba National Park, & October, $04^{\text {th }}-18^{\text {th }}, 2017$ \\
& Cat Hai district, Hai Phong city & November, $03^{\text {rd }}-10^{\text {th }}, 2017$ \\
2 & Gia Luan commune, Cat Hai district, Hai Phong city & April, $05^{\text {th }}-10^{\text {th }}, 2018$ \\
& & October, $19^{\text {th }}-21^{\text {st }}, 2017$ \\
3 & Hien Hao commune, Cat Hai district, Hai Phong city & November, $11^{\text {th }}-13^{\text {rd }}, 2017$ \\
& & April, $11^{\text {th }}-13^{\text {rd }}, 2018$ \\
4 & Phu Long commune, Cat Hai district, Hai Phong city & October, $22^{\text {td }}-24^{\text {th }}, 2017$ \\
& & November, $14^{\text {th }}-17^{\text {th }}, 2017$ \\
5 & Tran Chau commune, Cat Hai district, Hai Phong city & April, $14^{\text {th }}-15^{\text {rd }}, 2018$ \\
6 & Viet Hai commune, Cat Hai district, Hai Phong city & October, $25^{\text {th }}-26^{\text {th }}, 2017$ \\
7 & Xuan Dam commune, Cat Hai district, Hai Phong city & April, $18^{\text {th }}-20^{\text {th }}, 2018$ \\
& & April, $21^{\text {st }}-24$ th, 2018 \\
& & November, $18^{\text {th }}-19^{\text {th }}, 2017$
\end{tabular}

\subsection{Materials}

The surveys focused on general assessment of ecosystems and biodiversity conservation efforts within the park. Materials include published literatures and selected taxa inhabiting cave and mangrove ecosystems. The caves of Cat $\mathrm{Ba}$ were surveyed because they are home to many species endemic to either Cat $\mathrm{Ba}$ or Vietnam. On the other hand, many caves in the park are affected by tourism development while mangroves have been disturbed narrowed by aquatic cultivation. Literatures are saved at the Institute of Human Geography, Vietnam Academy of Social Sciences, animal specimens from caves were identified by experts of the Institute of Ecology and Biological Resources, Vietnam Academy of Science and Technology, Hanoi, Vietnam.

\subsection{Methods}

Interview and meetings were implemented over the survey periods (Table 1). Managers and rangers of $\mathrm{Cat} \mathrm{Ba} \mathrm{Na-}$ tional Park as well as selected local people were invited to informal meeting for interviewing and discussion on the status of biodiversity from the past to present, impact of implemented projects and programmes on biodiversity conservation, possible solutions must be carried out in coming time. All available documents containing data and information about diversity of the park were also gathered. To obtain data on impact on ecotourism on environment and biodiversity, observation and photographing were employed at almost all tourism caves within Cat Ba National Park. On the other hand, the field surveys also focused on bats to assess the impact of ecotourism on cave systems of the park since they are very sensitive to environment.

Bats were captured in the field following Thong (2011) [17], Thong et al. (2012a [23], 2012b [24], 2012c ) and Thong (2016). Mist nets in various sizes (12.0 m x $2.4 \mathrm{~m}$; $12.0 \mathrm{~m} \times 4.0 \mathrm{~m} ; 6.0 \mathrm{~m} \times 2.4 \mathrm{~m} ; 6.0 \mathrm{~m} \times 3.2 \mathrm{~m} ; 3.0 \mathrm{~m} \times 3.2$ $\mathrm{m} ; 3.0 \times 2.4 \mathrm{~m})$ and harp traps $(1.2 \mathrm{~m} \times 1.5 \mathrm{~m})$ were opened between 17:00 and 22:30 pm. Each captured bat was individually placed in a cotton bag and handheld following Sikes et al. (2011) [11]. Age and reproductive status were assessed following Brunet-Rossinni and Wilkinson (2009) [4] and Racey (2009) [10], respectively. Juveniles, pregnant and lactating females were released immediately at the capture sites to avoid negative impact in the conservation status of bats in their natural habitats. 
Echolocation calls of bats were recorded in inside a flight tent (3.0 m [length] x $3.0 \mathrm{~m}$ [width] x $2.0 \mathrm{~m}$ [height]) following Thong et al. (2011) using the PCTape system (480 $\mathrm{kHz}, 16$ bit). Selected call sequences with a good signal-tonoise ratio was analysed using the Selena software. Both PCTape and Selena are custom-made at the University of Tübingen, Germany. Signals were displayed as sonograms with a FFT (Fast Fourier Transformation) of 256, Hannwindow and zero-padding. Recordings from natural habitats of bats were also analysed for comparison with the calls of each species recorded inside flight tent as well as to assess foraging activities.

\section{Results and discussion \\ 3.1. An overview of biodiversity}

To our knowledge, Bourret (1942a [2], 1942b [3]) appeared as the first publications containing scientific data on biodiversity of $\mathrm{Cat} \mathrm{Ba}$ island and surroundings with records of bat and other mammal species. Furey et al. appeared as one of the documents containing scientific results of a general survey on both flora and fauna [8]. Subsequently, a number of surveys on biodiversity of the park. However, almost all surveys were emphased on selected taxa, including mammals, reptiles, amphibians and marine animals ([1]; [19]; [8]; [26]; [12]; [15]). To date, 1,585 plant species belonging to 850 genera, 187 families, 5 phyla are recorded from Cat Ba National Park (Table 1) [5]. Of which, 245 species are agriculture plants including Capsicum undatum, Ipomoea balatas, Ipomoea aquatica, Manihot esculenta, Oryza sativa, Capsicum frutescens and 6 species originated from other areas: Annona aquamosa, Croton oblongifolius, Delavaya toxocarpa, Polyalthia benth, Rhus semialata, Taractogenos sp. [5]. The known flora comprises 10 abundant families and 10 genera with considerably high number of species (Table 2).

Cat Ba National Park is also known as a home to a highly diverse mammal fauna comprising 58 species belonging to 19 families, 7 orders: Insectivora (1 family, 1 species), Scandenta (1 family, 1 species), Chiroptera (6 families, 23 species), Primates (1 family, 2 species), Carnivora (4 families, 11 species), Artiodactyla (1 family, 1 species) and Rodentia (5 families, 19 species) [CBNP]. However, several species listed in previous publications are still unconfirmed such as Neofelis nebulosa, Manis pentadactyla, Muntiacus mantjak. It must be considered that, due to legal exploitation of the Cat Ba Enterprise before 1986, forest and other natural resources on the islands were critically decreased. Therefore, populations of many species including Cat Ba Langur, which is endemic to CBNP was decreased critically from an estimate of "2500-2700 individuals during the 1960s down to 54-56 individuals in 2017 [8].

The bird fauna of Cat Ba National Park is still poorly studied. Results from a survey in 2011 by Do Quang Huy (sen su Cat Ba National Park 217), a total of 205 bird species belonging to 51 families, 17 orders are recorded from the park [5]. Reptiles and amphibians of the park were well studied over the past 15 years. To date, 47 reptile species belonging to 40 genera, 16 families, 2 orders and 23 amphibian species belonging to 15 genera, 5 families and 1 order are known from Cat Ba National Park. Of which, several species were recently described and would be endemic to the park: Goniurosaurus catbaensis, Liuixalus calcarius and Philautus catbaensis ([12]; [15]).

Fishes of the park received little attention from scientist. Almost all surveys on fishes of the park were carried out at saltwater lakes and submerged caves in the buffer zone of the park. Results from the surveys indicated that at least 30 fish species of 25 genera, 22 families are recorded from the park and surroundings. Of which, a number of fish species are considered for their high economic values such as Scatophagus argus, Siganus sutor, Lethrinus nebulosus.

Thung (2017) provided a review of research on marine plants and animals in the $\mathrm{Cat} \mathrm{Ba}-\mathrm{Ha}$ Long complex with records of 2147 species from Cat Ba National Park [26]. Among these marine species, 114 are listed in the IUCN Red List of the Threatened Species at different conservation levels.

Cat Ba National Park and Ha Long Bay appear as one of the most ideal landscape complex in Vietnam for bat research and conservation. Conservation actions of bats in in the park has been initiated since 2006 [16]. This special mammal species in the park have received a long historical research. As mentioned above, the first data on bat fauna on Cat Ba was published in Bourret (1942) with a new subspecies of little leaf-nosed bat (Hipposideros larvatus alongensis) based on the classification of 10 specimens collected in Ha Long. However, the author did not specify the sampling location. Possibly, 10 specimens were collected in Cat Ba island. In 1975, Topal compared the morphological characteristics of penile cartilage in some species of Leaf-nosed Bats family (Hipposideridae); among them "alongensis" was recorded as Hipposideros alongensis [13]. However, in 1993, Topal has identified "alongensis" as a subspecies of Hipposideros turpis alongensis when he analyzed and compared bat specimens collected in Vietnam, Japan and Thailand [14]. In 1997, a result of investigation and summation of information on mammal resources in $\mathrm{Cat} \mathrm{Ba}$ and its vicinity was published with the record of 6 species of bats: Cynopterus sphinx, Hipposideros armiger, $H$. larvatus, Pipistrellus javanicus, Scotophilus heathii, S. kuhli. Remarkably, on the first page of the document, the authors provided image of Aselliscus stoliczkanus but in the part of notification, it was identified as Pipistrellus javanicus. Hendrichsen et al. (2001) recorded Andersen's Leaf-nosed Bat (Hipposideros pomona) in Cat Ba. From 2002 to 2007, there had been some research results on bats of $\mathrm{Cat} \mathrm{Ba}$ and they were published on different scientific reviews, such as:the field survey report of the organization Frontier - Vietnam (classified the specimen of Hipposideros alongensis and Hipposideros turpis); the results of field investigation and updating species component of bats distributing in Cat $\mathrm{Ba}$; describing meticulously ultrasound of Rhinolophus marshalli; the first record of Hipposideros khaokhouayensis in Vietnam and named it in Vietnamese Catba's leaf-nosed bat. Cat Ba National Park was also the first place to study the ultrasounds of Murina harrisoni and some other bat species and also the standard location of Griffin's Leaf-nosed Bat (Hipposideros griffini) [18]. 
Table 2. Plant species recorded from Cat Ba National Park [5]

\begin{tabular}{clcccccc} 
& & \multicolumn{2}{c}{ Families } & \multicolumn{2}{c}{ Genera } & \multicolumn{2}{c}{ Species } \\
\cline { 3 - 7 } No. & Phyla & $\begin{array}{c}\text { Number of } \\
\text { speices }\end{array}$ & Percentage & $\begin{array}{c}\text { Number } \\
\text { of genera }\end{array}$ & Percentage & $\begin{array}{c}\text { Number of } \\
\text { species }\end{array}$ & Percentage \\
\hline 1 & Lycopodiophyta & 2 & 1.07 & 3 & 0.35 & 6 & 0.38 \\
2 & Equisetophyta & 1 & 0.53 & 1 & 0.12 & 1 & 0.06 \\
3 & Polypodiophyta & 16 & 8.56 & 32 & 3.76 & 63 & 3.97 \\
4 & Pinophyta & 6 & 3.21 & 14 & 1.65 & 24 & 1.51 \\
5 & Angiospermae & 162 & 86.63 & 800 & 94.12 & 1,491 & 94.07
\end{tabular}

Table 2. Common families and genera of plants in Cat Ba National Park [5]

\begin{tabular}{llcc|ccc} 
No. & Families & $\begin{array}{c}\text { Number of } \\
\text { speices }\end{array}$ & Percentage & Genera & $\begin{array}{c}\text { Number of } \\
\text { speices }\end{array}$ & Percentage \\
\hline 1 & Euphorbiaceae & 81 & 15.67 & Ficus & 30 & 25.21 \\
2 & Poaceae & 78 & 15.09 & Bauhinia & 11 & 9.24 \\
3 & Fabaceae & 73 & 14.12 & Ardisia & 11 & 9.24 \\
4 & Rubiaceae & 59 & 11.41 & Symplocos & 11 & 9.24 \\
5 & Moraceae & 43 & 8.32 & Castanopsis & 10 & 8.40 \\
6 & Caesalpiniaceae & 42 & 8.12 & Lithocarpus & 10 & 8.40 \\
7 & Lauraceae & 40 & 7.74 & Bambusa & 10 & 8.40 \\
8 & Asteraceae & 40 & 7.74 & Ormosia & 9 & 7.56 \\
9 & Rutaceae & 31 & 6.00 & Cinnamomum & 9 & 7.56 \\
10 & Meliaceae & 30 & 5.80 & Elaeocarpus & 8 & 6.72
\end{tabular}

\subsection{Recent records of bats}

Over the recent surveys, we recorded many species of bats in different habitats ranging from mangrove to karst forest. Remarkably, we recorded to raely documented species: Black-bearded Tomb Bat (Taphozous melanopogon) and Eastern bent-winged Bat (Miniopterus fuliginosus). This study results confirm the distribution of these two species in the park. Details of the records in previous publications and from recent survys are given as follows:

\subsubsection{Black-bearded Tomb Bat (Taphozous melanopogon)}

Dang Ngoc Can et al. (2008) recorded the distribution of Black-bearded Tomb Bat (Taphozous melanopogon) in Cat
Ba National Park [6]. However, the record was attributed to a technical error during the compilation process and the authors had no previous proof that recorded Black-bearded Tomb Bat in Cat Ba National Park (information confirmed by Vu Dinh Thong). The species of Black-bearded Tomb Bat was first recorded in Cat Ba National Park by Vu Dinh Thong et al. (2016). This species of bat was recorded in Hang Quan Y area and some study sites in Phu Long commune (Figure 1). Specimens are kept at the Department of Zoological Museum, Institute of Ecology and Biological Resources, Vietnam Academy of Science and Technology. The species emit "quansi-constant-frequency" echolocation calls with energy focuses on the second harmonic.

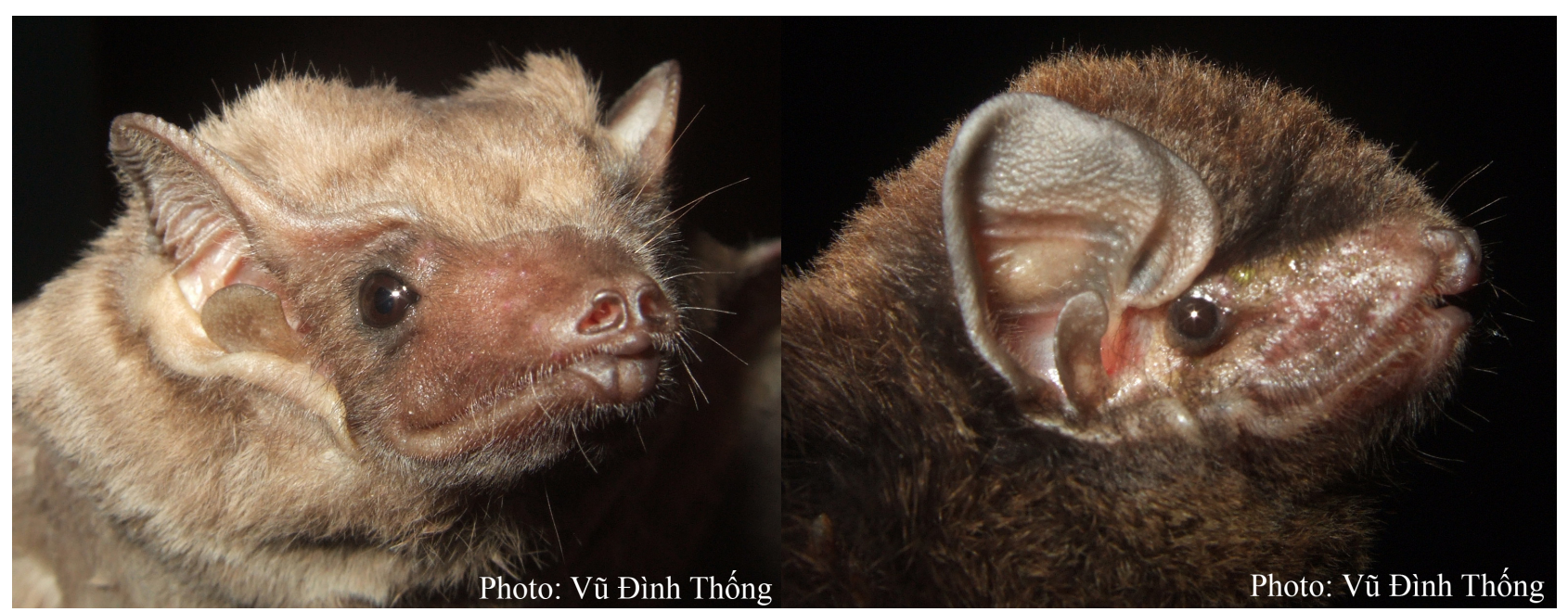

Figure 1. Morphology of face and ear of Taphozous melanopogon (left) and Miniopterus fuliginosus (right). 


\subsubsection{Eastern bent-winged Bat (Miniopterus fuliginosus)}

A record of 1 species belonging to the family of Longwinged Bat (Miniopteridae) in Abramov and Kruskop (2012) [1] was based on references of two previously published documents ([16]; Vu Dinh Thong and Furrey 2008). Results from the resent survey confirm the distribution of Miniopterus fuliginosus in the park. In fact, the classification of species belonging to the family of bent-winged bat (Miniopteridae) in Vietnam in general and individuals of bent-winged bat in Cat Ba National Park in particular require more research results with a combination of morphology, ultrasound and molecular biology in near future. This species emits "frequency-modulated" echolocation calls with energy focuses on the first harmonic.

\section{Conclusion}

Cat $\mathrm{Ba}$ National Park is an ideal for biodiversity research and conservation. Many species of plant and animals are recorded from the park, including the ones listed in the 2007 Red Data Book of Vietnam and the current IUCN Red List of the Threatened Species. Cat Ba Langur and Halong Leaf0nosed Bat are two of the species enedmic to the Cat Ba National Park and Vietnam. Conservation of these species requires continuous action plans based on ecological research. The regulations and law systems for biodiversity conservation have been applied successfully by the authorities and managers of Cat Ba National Park.

Acknowledgement: The authors express sincere thanks to the Institute of Human Geography of VASS and Cat Ba National Park for financial and administrative supports, respectively.

\section{References}

[1] Abramov A.V., Kruskop S.V., 2012. "The mammal fauna of Cat Ba island, northern Vietnam", Russian Journal of Theriology, 11(1): 57-72.

[2] Bourret R., 1942a. "Sur quelques petits Mammifères du Tonkin et du Laos", Comptes rendus du Conseil de Recherches Scientifiques de l'Indochine 2ème semestre: 27-30.

[3] Bourret R., 1942b. "Les mammifères de la collection du Laboratoire de Zoologie de l'École Supérieure des Sciences", Université Indochinoise, Hanoi, Vietnam.

[4] Brunet-Rossinni A.K., Wilkinson G.S., 2009. Methods for age estimation and the study of senescence in bats. In: Kunz T.H., Parsons S. (eds.) Ecological and Behavioral Methods for the Study of Bats, 2nd edition, Johns Hopkins University Press, Baltimore, pp. 315-325.

[5] CBNP (Cat Ba National Park, unpublished. Investment plant for development and conservation of biodiversity in Cat ba National Park, 148pp.

[6] Đặng Ngọc Cần, Endo H., Nguyễn Trường Sơn, Oshida T, Lê Xuân Cảnh, Đặng Huy Phương, Lunde D.P., Kawada S.-I., Hayashida A., Sasaki M., 2008.
Danh lục các loài thú hoang dã Việt Nam, Hà Nội, Việt Nam: 68-182.

[7] Furey, M.N. Le Xuan Canh, Fanning, E., 2002. Cat Ba National Park: Biodiversity Survey 1999, Frontier Vietnam Environmental Research Report 20, Society for Environmental Exploration, UK and Institute of Ecology and Biological Resources, Hanoi.

[8] Leonard, N., unpublished report. 2017. The Cat Ba Langur (Trachypithecus poliocephalus) in the complex of World Heritage Site Nomination.

[9] Le Xuan Canh, Cao Van Sung, Lee S.D., 1997. "Mammal resources of $\mathrm{Cat} \mathrm{Ba}$ and surrounding areas in Vietnam", Ecosystem and biodiversity of Cat Ba National Park and Ha Long Bay, 147-159.

[10] Racey P.A., 2009. Reproductive assessment in bats. In: Kunz T.H., Parsons S. (eds.) Ecological and Behavioral Methods for the Study of Bats, 2nd edition, Johns Hopkins University Press, Baltimore, pp. 249264.

[11] Sikes R.S., W.L. Gannon, and the Animal Care and Use Committee of the American Society of Mammalogists, 2011. Guidelines of the American Society of Mammalogists for the use of wild mammals in research. Journal of Mammalogy 92: 235-253.

[12] Tao, N.T., N.V. Thinh, P.T. Cuong, unpublished report. New discoversy of amphibians from cat $\mathrm{Ba} \mathrm{Ar}-$ chipelago: implications for conservation.

[13] Topál G., 1975. "Bacula of some Old World leafnosed bats (Rhinolophidae and Hipposideridae, Chiroptera: Mammalia)", Vertebrata Hungarica, 16, pp. 21-53.

[14] Topál G., 1993. "Taxonomic status of Hipposideros larvatus alongensis Bourret, 1942 and the occurence of H. turpis Bangs, 1901 in Vietnam (Mammalia, Chiroptera)" Acta Zoologica Hungarica, 39, pp. 267288.

[15] Truong, N.T., N.N. Hai, T. Ziegler, unpublished report. The reptile fauna of Cat $\mathrm{Ba}$ Archipelago: a unique biological resources with a high level of local endemism and important conservation significance.

[16] Vu Dinh Thong, 2007. Bat Conservation at Cat Ba Biosphere Reserve, North-east Vietnam. Conservation Leadership Programme. Unpublished report: $18 \mathrm{pp}$.

[17] Vu Dinh Thong, 2011. Systematics and echolocation of rhinolophoid bats (Mammalia: Chiroptera) in Vietnam. PhD Thesis, University of Tuebingen, Tuebingen, Germany, 258 pp.

[18] Vu Dinh Thong, 2014. "Acoustic identification and taxonomic remarks of horseshoe bats (Chiroptera: rhinolophidae) in Cat Ba National Park, north-eastern Vietnam", Proceedings of the first international VAST-BAS conference, pp. 323-328.

[19] Vũ Đình Thống, 2016. Đánh giá tính đa dạng và hiện trạng của các loài dơi ở khu dự trữ sinh quyển Cù Lao Chàm-Hội An. Tạp chí Sinh học, 38(1): 33-38. 
[20] Vũ Đình Thống, Furey N.M., 2008. "Thành phần loài dơi hiện biết ở Khu dự trữ Sinh quyển Cát Bà”, Tạp chí Sinh học, 30(3), pp. 73-77.

[21] Vu Dinh Thong, Dietz C., Schnitzler H.-U., Denzinger A., Furey N.M., Borissenko A., Bates P.J.J., 2008. "First record of Hipposideros khaokhouayensis (Chiroptera: Hipposideridae) from Vietnam”, Journal of Science of HNUE, 53(5), pp. 138-143.

[22] Vu Dinh Thong, Dietz C., Denzinger A., Bates P.J.J., Furey N.M., Csorba G., Hoye G., Thuy L.D., and Schnitzler H.-U., 2011. Further records of Murina tiensa from Vietnam with first information on its echolocation calls. Hystrix-Italian Journal of Mammalogy, 22(1): 129-138.

[23] Vu Dinh Thong, Dietz C., Denzinger A., Bates P. J. J., Puechmaille S. J., Callou C., Schnitzler H.-U., 2012a. Resolving a mammal mystery: the identity of Paracoelops megalotis (Chiroptera: Hipposideridae). Zootaxa, 3505: 75-85.

[24] Vu Dinh Thong, Puechmaille S.J., Denzinger A., Bates P.J.J., Dietz C., Csorba G., Soisook P., Teeling E.C., Matsumura S., Furey N., Schnitzler H.U., 2012. Systematics of the Hipposideros turpis complex and a description of a new subspecies from Vietnam. Mammal Review, 42: 166-192.

[25] Vu Dinh Thong, Puechmaille S.J., Denzinger A., Dietz C., Csorba G., Bates P.J.J., Teeling E.C., Schnitzler H.U., 2012c. A new species of Hipposideros (Chiroptera: Hipposideridae) from Vietnam. Journal of Mammalogy, 93: 1-11.

[26] Thung, D. C. Unpublished report. Diversity of marine plant and animals of Ha Long-Cat Ba complex. 